\title{
DIFFERENCES IN VOLUNTARY COUNSELLING AND TESTING (VCT) COMPLIANCE RATES AS WELL AS FACTOR THAT INFLUENCE WPS AND WPSTL AT MADIUN REGENCY
}

\author{
Hanifah Ardiani' ${ }^{1}$ Avicena Sakufa Marsanti ${ }^{2}$ \\ Email : ardiani.hanifah@gmail.com \\ 1,2Prodi Kesehatan Masyarakat, Stikes Bhakti Husada Mulia Madiun, Indonesia
}

\section{ABSTRACT}

The number of WPS and WPSTL visits in 2017 on VCT services in localization and karaoke places in Madiun Regency is still relatively low. According to the Ministry of Health, VCT services must be done 1 time in 3 months or 4 times a year (100\%). In 2017 in Madiun Regency from the target of 100\% risk group doing VCT, only reached $42.7 \%$ who did VCT in the WPS group and $72.7 \%$ in the WPSTL group. Cases of HIV / AIDS from year to year have increased significantly enough to require further treatment, especially in Madiun Regency. Of the 197 WPS and WPSTL in Madiun Regency, 89 (45.18\%) were HIV/AIDS positive. One of the causes of the high incidence of HIV / AIDS cases in Madiun Regency is due to the low level of VCT service visits. This study used a cross sectional study design with a sample number of 49 WPS and 19 WPSTL based on the results of the calculation of the slovin sample formula. Sampling techniques using purposive sampling. The free variables in the study were peer knowledge, attitudes and support, while the bound variables were VCT compliance. Data analysis uses univariate, bivariate analysis using chi square and multivariate with logistic regression. External to this study is an article published in an accredited national journal.

\section{ABSTRAK}

Jumlah Kunjungan WPS dan WPSTL tahun 2017 pada layanan VCT di lokalisasi dan tempat karaoke di Kabupaten Madiun masih tergolong rendah. Menurut kemenkes RI pelayanan VCT harus dilakukan 1 kali dalam 3 bulan atau 4 kali dalam setahun (100\%). Pada tahun 2017 di Kabupaten Madiun dari target 100\% kelompok resiko melakukan VCT, baru tercapai $42,7 \%$ yang melakukan VCT pada kelompok WPS dan 72,7\% pada kelompok WPSTL. Kasus HIV/AIDS dari tahunketahun mengalami peningkatan yang cukup signifikan sehingga membutuhkan penanganan lebih lanjut khususnya di Kabupaten Madiun. Dari 197 WPS dan WPSTL di Kabupaten Madiun, 89 (45,18\%) diantaranya positif mengidap HIV/AIDS. Salah satu penyebab tingginya angka kejadian kasus HIV/AIDS di Kabupaten Madiun disebabkan tingkat kunjungan layanan VCT rendah. Penelitian ini menggunakan desain studi cross sectional dengan jumlah sampel 49 WPS dan 19 WPSTL berdasarkan hasil perhitungan rumus sampel slovin. Teknik pengambilan sampel menggunakan purposive sampling. Variabel bebas dalam penelitian ini adalah pengetahuan, sikap dan dukungan teman sebaya, sedangkan variabel terikatnya yaitu kepatuhan VCT. Analisis data menggunakan analisis univariat, bivariat menggunakan chi square dan multivariate dengan regresi logistik. Luaran dari penelitian ini adalah artikel diterbitkan di jurnal nasional terakreditasi.

\section{ARTICLE INFO}

Keywords:

VCT compliance, influencing factors, WPS, WPSTL

DOI:

10.24252/kesehatan.v14i2.23726

Kata kunci :

Kepatuhan VCT, Faktor yang mempengaruhi, WPS, WPSTL

\section{Introduction}

The first health service in the prevention of HIV transmission is Voluntary Counseling and Testing (VCT) which includes prevention, treatment and treatment efforts. VCT begins with counseling conducted by a VCT counselor. Counseling aims to provide basic information about HIV/AIDS and the benefits of VCT. HIV testing is recommended as early as 1 month after the last risky behavior / exposure and repeated 3 months after the risky behavior ends. The test results are not infected with HIV if the HIV screening is done for 3 months after the last risky behavior is non-reactive. In principle, the new immune system forms antibodies up to 3 months after exposure to risky behaviors, this period is called the window period. The test in the first month is done because at that time it can be detected, but if the results are non-reactive it needs to be repeated every 3 months after exposure(1).

The number of visits of female sex workers (WPS) and women indirect sex workers (WPSTL) in 2017 on VCT services in localization and karaoke places in Madiun Regency is still relatively low. According to the Ministry of Health, VCT services must be done 1 time in 
3 months or 4 times a year (100\%). In 2017 in Madiun Regency from the target of $100 \%$ risk group doing VCT, only reached $42.7 \%$ who did VCT in the WPS group and $72.7 \%$ in the WPSTL group. This is still a problem because of the 197 WPS and WPSTL in Madiun Regency, 89 (45.18\%) are HIV/AIDS positive. The high prevalence of HIV/AIDS in WPS and WPSTL requires VCT compliance in order to prevent transmission(2).

One of the variables that can support VCT is knowledge and attitude. Knowledge is the result of knowing and this occurs after a person sensing a particular object. (3) While attitudes can be influenced by many things, apart from knowledge factors are also influenced by cultural factors, others who are considered important, mass media, personal experiences, educational institutions, religious institutions and emotions from within the individual. Attitudes towards VCT in WPS and WPSTL can be positive or negative, positive attitudes of action tendencies are supportive in VCT while negative attitudes tend to act is to avoid VCT checks(4).

Cases of HIV / AIDS from year to year have increased significantly enough that it requires further treatment, especially in Madiun Regency. One of the causes of the high incidence of HIV / AIDS cases in Madiun Regency is due to the low level of VCT service visits. This is supported by the number of VCT visits made in January 2018 in one of the localizations out of a total of 14 WPS working in the localization only 8 (57\%) WPS do VCT. Until now there have been no studies that have managed to find a drug that can kill the HIV virus, therefore early detection of HIV / AIDS disease can be done with VCT services regularly every 3 months. The main targets of VCT are risk groups that have a high risk of HIV / AIDS including WPS, WPSTL. (2) This is what makes researchers interested in researching differences in voluntary counselling and testing (VCT) compliance levels and the factors that affect it in WPS and WPSTL in Madiun Regency.

\section{Methods}

Research is quantitative analytics with a cross sectional approach. The research is conducted at the same time(5). The research location was conducted in localization, dimly lit stalls and karaoke places in Madiun Regency. The population of this study is all WPS and WPSTL on localization or dimly lit stalls and karaoke places located in Madiun Rege. The number of WPS as many as 142 people and WPSTL in Madiun regency as many as 55 people (based on data in 2017, before the official localization was dissolved). The sampling technique used is purposive sampling(6). Data collection uses interviews using questionnaires. With inclusion criteria Willing to be a research respondent, already working at least from 2018 (2 years before the Covid-19 pandemic), WPS with the criteria of peddling sex directly either based at home or localization or working on the street(7). WPSTL with the criteria of not peddling sex directly or working in entertainment businesses such as karaoke, massage parlors, bars that supplement their income by selling credits. But not all those who work in the place are indicated to sell sex(7). Data is analyzed using univariate, bivariate(chi-square) and multivariate analysis (logistic regression test) with $\alpha=0.05$.

\section{Results}

\section{Univariat Analysis}

Respondents characteristics were based on education level, marital status, age and vct compliance level. Can be see in Table 1 
Tabel 1. Distribution of Respondent Characteristics

\begin{tabular}{|c|c|c|c|c|c|}
\hline \multirow[b]{2}{*}{ NO } & \multirow[b]{2}{*}{ Characteristic } & \multicolumn{2}{|c|}{ WPS } & \multicolumn{2}{|c|}{ WPSTL } \\
\hline & & Sum & $\begin{array}{c}\text { Percentage } \\
\text { (\%) }\end{array}$ & Sum & $\begin{array}{c}\text { Percentage } \\
\text { (\%) }\end{array}$ \\
\hline \multirow[t]{5}{*}{1} & Level of Education & & & & \\
\hline & Not School & 10 & 20,4 & 0 & 0 \\
\hline & End of Primary School & 22 & 44,9 & 0 & 0 \\
\hline & $\begin{array}{l}\text { Finished Junior High } \\
\text { School }\end{array}$ & 13 & 26,5 & 10 & 52,6 \\
\hline & Finished High School & 4 & 8,2 & 9 & 47,4 \\
\hline \multirow[t]{4}{*}{2} & Marital Status & & & & \\
\hline & Married & 39 & 79,6 & 8 & 42,1 \\
\hline & Unmarried & 2 & 4,1 & 3 & 15,8 \\
\hline & Widow & 8 & 16,3 & 8 & 42,1 \\
\hline \multirow[t]{4}{*}{3} & Age & & & & \\
\hline & $<20$ years & 0 & 0 & 7 & 36,8 \\
\hline & 20-35 years & 11 & 22,4 & 10 & 52,6 \\
\hline & $>35$ years & 38 & 77,6 & 2 & 10,5 \\
\hline \multirow[t]{3}{*}{4} & VCT Compliance Rate & & & & \\
\hline & Obedient & 14 & 28,6 & 4 & 21,1 \\
\hline & Disobedient & 35 & 71,4 & 15 & 78,9 \\
\hline
\end{tabular}

\section{Bivariat Analysis}

Bivariate analysis based on the independent variables namely knowledge, attitudes, and peer support with the dependent variable being the level of VCT compliance. Can be see in Table 2 .

Tabel 2. Bivariat Analysis

\begin{tabular}{|c|c|c|c|c|c|c|c|c|}
\hline \multirow{2}{*}{ No } & \multirow{2}{*}{ Variable } & \multicolumn{2}{|c|}{ Obedient } & \multicolumn{2}{|c|}{ Disobedient } & \multirow{2}{*}{ P-value } & \multirow{2}{*}{ POR } & \multirow{2}{*}{$\begin{array}{c}95 \% \\
\text { CI }\end{array}$} \\
\hline & & $\mathrm{N}$ & $\%$ & $\mathrm{n}$ & $\%$ & & & \\
\hline \multirow[t]{3}{*}{1} & Knowledge & & & & & & & \\
\hline & Good & 15 & 48,4 & 16 & 51,6 & $0,001^{*}$ & 10,63 & 2,687- \\
\hline & Not Good & 3 & 8,1 & 34 & 91,9 & & & 42,008 \\
\hline \multirow[t]{3}{*}{2} & Attitude & & & & & & & \\
\hline & Positive & 15 & 45,5 & 18 & 54,5 & $0,002^{*}$ & 8,89 & $2,264-$ \\
\hline & Negative & 3 & 8,6 & 32 & 91,4 & & & 34,893 \\
\hline \multirow[t]{3}{*}{3} & $\begin{array}{l}\text { Peer } \\
\text { Support }\end{array}$ & & & & & & & \\
\hline & Support & 12 & 29,3 & 29 & 70,7 & $0,716^{* *}$ & 1,45 & $0,468-$ \\
\hline & $\begin{array}{l}\text { Does not } \\
\text { support }\end{array}$ & 6 & 22,2 & 21 & 77,8 & & & 4,481 \\
\hline
\end{tabular}

Keterangan: * related because P-value $<0,05$

** unrelated but included in multivariate analysis.

\section{Multivariat Analysis}

The results of bivariate analysis show that the variables that can go into multivariate analysis are knowledge and attitudes. The results of the analysis can be observed in Table 3 . 
Differences in Voluntary Counselling and Testing (VCT) Compliance Rates as well as Factor That Influence Wps and Wpstl at Madiun Regency

Tabel 3. Multivariat Analysis

\begin{tabular}{rlrrrr}
\hline No & Variabel & Value B & aPOR & 95\% CI & P-value \\
\hline 1 & Knowledge & 1,751 & 5,76 & $1,313-25,258$ & 0,020 \\
2 & Attitude & 1,603 & 4,97 & $1,124-21,949$ & 0,034 \\
& Constanta & $-3,042$ & & & \\
\hline
\end{tabular}

\section{Discussion}

\section{Univariat Analysis}

\section{A. Characteristics of Respondents Based on Education Level}

Based on table 1 above, it can be seen that the education level of respondents with WPS status mostly graduated from primary school (44.9\%) and at least finished high school $(8.2 \%)$. While WPSTL mostly finished junior high school $(52.6 \%)$ and no one did not go to school and did not finish primary school.

\section{B. Characteristics of Respondents Based on Marital Status}

Based on table 1 above it can be seen that wps marital status is mostly married (79.6\%) and at least unmarried (4.1\%). WPSTL is mostly married and widowed (42.1\%) and unmarried $(15.8 \%)$.

\section{Characteristics of Respondents based on Age}

Based on table 1 above, it can be seen that respondents with WPS status are mostly $>35$ years old $(77.6 \%)$ and there is no age $<20$ years. WPSTL is mostly $20-35$ years old $(52.6 \%)$ and at least $>35$ years old $(10.5 \%)$.

\section{Characteristics of Respondents Based on VCT Compliance Level}

Based on table 1 above it can be seen that respondents who are WPS status with a compliance VCT compliance rate $(28.6 \%)$. While WPSTL with a compliance VCT compliance rate $(21.1 \%)$.

\section{Bivariat Analysis.}

A. Influence of Knowledge on VCT compliance levels on WPS and WPSTL in Madiun Regency

Based on table 2. The results of knowledge variables to vct compliance levels are known that most respondents who are obedient have good knowledge (48.4\%) compared to respondents whose knowledge is not good (8.1\%).

Data processing results show that the value of $p$ value $0.001(\mathrm{p}<0.05)$ which means the influence between knowledge on vct compliance levels in WPS and WPSTL in Madiun Regency. The results are supported by a POR value $(95 \%$ CI $)=10.63(2,687-42,008)$ which means respondents with good knowledge have a 10.63 times greater chance of complying with VCT.

Knowledge is the result of knowing and this happens after a person sensing a particular object. A person's behavior will be more lasting if based on knowledge because health knowledge about a thing is a factor that needs to exist before healthy behavior. Knowledge is a very important domain for the help of one's actions. Knowledge is needed as an encouragement in giving rise to attitudes and behaviors, especially behavior to perform VCT(8). According to factors that affect knowledge can be divided into two, namely internal factors and external factors. Internal factors include education. Where, the higher a person's education, the easier it is to get and receive information(3). 
This is in line with research on the relationship of WPS knowledge about VCT to VCT behavior at Griya ASA PKBI Clinic in Semarang City(9). In addition, research conducted by on the identification of the characteristics of Indirect Sex Worker Women (WPSTL) against $\operatorname{HIV}(10)$.

From the above explanation can be concluded, respondents' knowledge of HIV and VCT and other prevention efforts not only comes from formal education, but can also come from other sources (health workers, KPAD, family, peers, and others) that can contribute in improving respondents' understanding of HIV transmission prevention and VCT examinations.

\section{B. Influence of Attitude on VCT compliance level on WPS and WPSTL in Madiun Regency}

Based on table 2. The results of attitude variables towards VCT compliance levels are known that the vast majority of respondents with a positive attitude by obediently doing VCT (45.5\%) compared to respondents with negative attitudes by obediently doing VCT (8.6\%).

Data processing results show that the value of $p$ value $0.002(\mathrm{p}<0.05)$ which means the influence between attitudes to vct compliance levels in WPS and WPSTL in Madiun Regency. The results are supported by a POR value $(95 \% \mathrm{CI})=8.89(2,264-34,393)$ which means respondents with a positive attitude have a risk of 8.89 times greater to comply with VCT.

An attitude is a reaction or response of a person who is still closed to a stimulus or object. The manifestation of this attitude cannot be immediately seen, but can only be interpreted in advance from its closed behavior(8). Factors that can affect a person's attitude are one of personal experiences and someone who is considered important where personal experience must be able to leave a strong impression in order to be used as the basis for the formation of a good attitude. While the influence of others who are considered important is also a factor that influences attitudes where individuals tend to have attitudes that are in line with people who they consider important because they are motivated by the desire to avoid conflict with people they think are important(3).

This is in line with research showing that there is a relationship between knowledge and hiv VCT examination attitudes in WPS in the Duren Bandungan Health Center Work Area(11). In addition, research shows that there is a link of pimping support to WPSTL sexual behavior in HIV/AIDS prevention efforts(12).

From the above explanation can be concluded that a person's personal experience will affect one's attitude, where if a person gets a good personal experience then his attitude will be positive towards an object. In addition, someone who is considered important is one of them is the caretaker or power of attorney in both locations (Sarmi and Liposos). Where from the two locations can be invited to cooperate with KPAD and Puskesmas to inform WPS and WPSTL who are in each location at the time of vct. VCT.

\section{Influence of Peer Support on VCT compliance levels on WPS and WPSTL in Madiun Regency}

Based on table 2, peer support variable results for VCT compliance levels found that the vast majority of respondents with supportive peer support dutifully did VCT (29.3\%) compared to respondents with less supportive peer support by compliant vct $(22.2 \%)$.

Data processing results showed that the $p$ value of $0.716(p<0.05)$ which means there was no influence between peer support on VCT compliance levels in WPS and WPSTL in Madiun Regency. The results were supported by a POR value $(95 \% \mathrm{CI})=1.45(0.468-4,481)$ which 
means respondents with supportive peer support have a 1.45 times greater risk of complying with VCT.

Friend or community encouragement, encouragement from the surrounding environment has a significant influence on a person's behavior(8). This contradicts research that friend or community encouragement has an effect on the willingness to do VCT. Encouragement can be in the form of information and motivation, encouragement can be obtained from the environment of friends, family, couples, and the community(13).

From the above explanation can be concluded that peer support is not WPS / WPSTL to comply with VCT. So the possibility to get a boost to the decision to do VCT does not exist at all. This form of support does not have to be positive, but there are also those that lead to negative things, and plunge respondents not to do VCT regularly. The encouragement of friends who were initially done such as giving advice when there are other friends do not want to do VCT or WPS / WPSTL listen and share stories even open and trust each other only temporarily, but respondents can always be affected in the long term due to encouragement from health workers and larger KPAD. The provision of information to cause awareness is realized by always reminding each month and always providing exposure to information.

\section{Multivariat Analysis}

Based on table 3.The most influential factor to VCT compliance on WPS and WPSTL is knowledge with aPOR $(95 \% \mathrm{CI})=5.76(1,313-25,258)$. Another factor affecting VCT compliance is attitude with aPOR $(95 \% \mathrm{CI})=4.97(1,124-21,949)$.

\section{Conclusion}

Most of the education levels of respondents who are WPS respondents educated junior high school with a percentage of $26.5 \%$, while the education level of respondents who are WPSTL status is mostly respondents educated junior high school with a percentage of $52.6 \%$. Most of the marital status of WPS status is married with a percentage of $79.6 \%$, while the marital status of respondents who are WPSTL status is married and widowed with a percentage of $42.1 \%$. Most respondents who are WPS age $>35$ years with a percentage of $77.6 \%$, while respondents who are WPSTL with the age of 20-35 years with a percentage of $52.6 \%$, There is An Influence of Knowledge on vct compliance rates in WPS and WPSTL in Madiun Regency, There is an influence on vct compliance rates in WPS and WPSTL in Madiun Regency and the most important factors. Influential knowledge with a value of B 1,751 and Attitude value B 1,603.

\section{Suggestion}

Further improving Mobile VCT, especially the accuracy of VCT schedules to populations such as WPS and WPSTL, provides support to wps and WPSTL to comply with VCT and the public should improve information about HIV / AIDS, especially about the way hiv / AIDS transmission is expected so that people who have risky behaviors can immediately do VCT.

\section{References}

1. Kementrian Kesehatan RI. Keputusan Menteri Kesehatan RI No 1507/MENKES/SK/X/2005 tentang Pedoman Pelayanan Konseling dan Testing HIV/AIDS Secara Sukarela. In 2005.

2. Komisi Penanggulangan AIDS (KPA) Daerah Kabupaten Madiun. Data Penderita HIV\&AIDS berdasar temuan di kab. Madiun. Madiun KPAD Kab Madiun. 2017;

3. Wawan dan Dewi. M. Teori dan Pengukuran Pengetahuan, Sikap dan Perilaku Manusia. In Yogyakarta: Nuha Medika; 2011. 
4. Azwar. Sikap Manusia Teori dan Pengukurannya. In: Yogyakarta: Pustaka Pelajar Offset. 2009.

5. Chandra B. Metodologi Penelitian Kesehatan. In: Jakarta : Buku Kedokteran EGC. 2013.

6. Sugiyono. Metode Penelitian Kuantitatif, Kualitatif, dan R\&D. In: Bandung: Alfabeta. 2017.

7. KPAN. Strategi dan Rencana Aksi Nasional Penanggulangan HIV/AIDS. In: Jakarta: Komisi Penanggulangan AIDS Nasional. 2010.

8. Notoatmodjo S. Promosi Kesehatan dan Ilmu Perilaku. Jakarta: Rineka Cipta; 2007. 135 p.

9. Siti Roudhotul Jannah, Fery Agusman HW. Hubungan pengetahuan wanita pekerja seks (WPS) tentang VCT terhadap perilaku (WPS) tentang VCT di klinik Griya Asa PKBI. Semarang J keperawatan. 2013;

10. Astuti DA. Identifikasi Karakteristik Wanita Pekerja Seks Tidak Langsung (WPSTL) Terhadap HIV. Prodi Kebidanan Progr Magister STIKES Aisyah Yogyakarta. 2014;

11. Putri Rahma Dini LI. Hubungan Antara Pengetahuan Dan Sikap Terhadap Pemeriksaan VCT HIV Pada WPS di Wilayah Kerja Puskesmas Duren Bandungan. Kebidanan dan Kesehat. 2020;11(2).

12. Aditya Yuda Pratama. Faktor-Faktor Yang Mempengaruhi Perilaku Seksual Wanita Pekerja Seksual Tidak Langsung (WPSTL) Dalam Upaya Pencegahan HIV/AIDS. Ilmu Kesehat Masy. 2016;

13. Risanita. Faktor Predisposing, Enabling, dan Reinforcing Dalam Pemanfaatan VCT Oleh Laki-Laki Seks Dengan Laki-Laki (LSL) di Malang. Skripsi, Univ Airlangga. 2016; 